\title{
Micobactérias atípicas em biopróteses: causa potencial de endocardite com culturas negativas
}

\author{
Ivan S. J. CASAGRANDE*, José LUCCIOLA*, Cláudio A. SALLES*, Belo Horizonte, MG.
}

RBCCV

\begin{abstract}
CASAGRANDE, I. S. J.; LUCCIOLA, J.; SALLES, C. A. - Micobactérias atípicas em biopróteses: causa potencial de endocardite com culturas negativas. Rev. Bras. Cir. Cardiovasc., 1 (1): 40-43, 1986.

RESUMO: O crescimento de micobactérias atipicas foi observado em estudos experimentais in vitro de fragmentos de válvulas aórticas porcinas após tanning em solução de glutaraldeido a $0,625 \%$. Foram incubados 100 fragmentos de valvas distintas em 4 meios de cultura diferentes, em um total de 400 culturas, utilizando-se os meios de Thioglycollate, Brain-Heart-Infusion, Sabouraud-Dextrose líqüido e Micosel, que permaneceram estéreis por 72 horas. Prolongando-se o tempo de incubação e utilizando-se técnicas especiais de repique e meios especiais para as subculturas, verificou-se o crescimento de micobactérias atípicas a partir do 5 : dia, em $23 \%$ das amostras, a partir de culturas nos meios de Thioglycollate e Sabouraud. identificados laboratorialmente como Mycobacterium chelonei. Testes posteriores demonstraram resistência desta micobactéria à ação bactericida do glutaraldeído e sua eliminação completa ocorreu após a ação do formaldeido associado ao surfactante.
\end{abstract}

DESCRITORES: biopróteses cardiacas; endocardite; micobactérias, atipicas.

\section{INTRODUÇĀO}

A patogenia e a epidemiologia das infecçōes humanas por outras micobactérias, que não o bacilo da tuberculose, têm sido objeto de muita investigação clínica, nas últimas três décadas, e um número crescente de publicações com relatos de casos de infecções causadas por essas bactérias tem surgido na literatura ${ }^{11}{ }^{14}$.

Em 1968, GERACl et alii ${ }^{3}$ relataram, pela primeira vez na literatura médica, um caso de endocardite por micobactérias atípicas do grupo IV de Runyon, também denominadas micobactérias de crescimento rápido, que englobam o complexo fortuitum-chelonei. Este grupo de micobactérias é encontrado, freqüentemente, na natureza e no solo e as condições climáticas de umidade e baixa temperatura favorecem o seu crescimento ${ }^{3,13}$.

Doenças humanas, no entanto, provocadas por esses microorganismos eram consideradas raras ${ }^{17}$. As infecções mais freqüentes são caracterizadas por lesões cutâneas e abscessos provocados por ferimentos com arma de fogo, acidentes de motocicletas e ferimentos contraídos em atividades de jardinagem, nos quais, geralmente, existe um contacto direto com o solo, favorecendo a contaminação dessas feridas ${ }^{4}$. 
Em 1977, O CENTER FOR DISEASE CONTROL ${ }^{1}$ identificou a presença de Mycobacterium chelonei em culturas de 4 biopróteses cardíacas de porcino preservadas em glutaraldeído a $0,2 \%$, fabricadas pelo laboratório Hancock*, e LASKOWSKI et alii ${ }^{6}$ relataram 8 casos de pacientes que receberam biopróteses contaminadas com esta micobactéria, fornecidas pelo mesmo Laboratório.

Foram relatados na literatura alguns casos isolados de endocardite infecciosa causada por micobactérias atípicas em portadores de bioprótese de porcino Hancock, contaminadas com Mycobacterium chelonei de alguns lotes de válvulas fabricadas entre outubro de 1975 e agosto de $1976^{7}$, 12, 15

Outros casos de endocardite por micobactérias do grupo fortuitum chelonei têm sido relatados após cirurgia de revascularização miocárdica e em portadores de próteses cardiacas mecânicas, assim como em infecções do esterno e da ferida operatória provocados por fontes não identificadas ${ }^{9}$. 10. 13

\section{MATERIAL E MÉTODO}

Foi elaborado um estudo experimental com a finalidade de estudar a etiopatogenia da contaminação das biopróteses de porcino por micobactérias atipicas, assim como procurar identificar as possiveis fontes de contaminação, os prováveis microorganismos envolvidos e a sua resistência in vitro às substâncias utilizadas na fixação e preservação de tecidos biológicos. Procurou-se, através desta pesquisa, definir condições seguras de esterilidade das biopróteses.

Foram utilizados fragmentos de valvas aórticas, cujos folhetos eram, concomitantemente, preparados para a confecção de biopróteses seguindo-se as diversas fases do preparo do tecido biológico. São reproduzidas, no estudo destes fragmentos, exatamente as mesmas condições de manuseio industrial a que o tecido biológico é submetido no laboratório para a fabricação das biopróteses. **

Válvulas aórticas de porcino foram obtidas em abatedouros industriais, em condiçōes de higiene locais, logo após o abate dos animais, e merguIhadas em solução salina balanceada e tamponada com fosfato em pH 7,4 a $4^{\circ} \mathrm{C}$ e imediatamente transportadas para o laboratório. A partir daí, utilizam-se procedimentos estéreis procedendo-se, inicialmente, à remoção dos tecidos adjacentes, seguindo-se a fixação do material biológico pelo processo de tanning em glutaraldeído a uma concentração de $0,625 \%$ em solução salina balanceada e tamponada com fosfato em pH 7,4.

O material do presente estudo foi constituído por 100 fragmentos de valvas distintas já previamente submetidos ao processo. de tanning em glutaraldeído, que foram colhidos com rigorosa assepsia e incubados em 4 meios de cultura diferentes, num total de 400 culturas.

Foram empregados os meios de Thioglycollate e Brain-Heart-Infusion a $37^{\circ} \mathrm{C}$ e os meios de Sabouraud-Dextrose liqüido e Micosel à temperatura ambiente. As 400 culturas foram mantidas nestas condições de incubação no laboratório, sob rigorosos cuidados de assepsia, durante 72 horas.

\section{RESULTADOS}

Todas as 400 culturas permaneceram estéreis no período de 72 horas. Entretanto, prolongando-se esse tempo de incubação, verificou-se, entre o 5 ? e o 10: dias, o aparecimento de películas na superfície do meio de Thioglycollate em 23 culturas e granulações no fundo dos tubos contendo meio de Sabouraud-Dextrose líqüido também em 23 culturas, correspondentes a fragmentos das mesmas valvas. A coloração pelo Gram evidenciou a presença de bastonetes Gram-lábeis e a coloração Ziehl-Nielsen revelou tratar-se de germes fortemente álcool-ácido resistentes.

Repiques posteriores destas películas e granulaçōes em meio de Loewenstein-Jensen revelaram o crescimento de colônias cujas características sugeriam tratar-se de uma "micobactéria de crescimento rápido" pertencente ao grupo IV de Runyon (complexo fortuitum-chelonei).

Essas colônias foram submetidas a provas laboratoriais de identificação bacteriana, que revelaram tratar-se de Mycobacterium-chelonei, identificadas através das seguintes características: crescimento rápido a temperaturas entre 24 e $37^{\circ} \mathrm{C}$; ausência de crescimento à temperatura de $45^{\circ} \mathrm{C}$; colônias de rugosidade intermediária e não fotocromogênicas; prova de niacina negativa; ausência de redução do nitrato; catalase a $68^{\circ} \mathrm{C}$ positiva; crescimento em meio de MacConkey isento de cristal violeta positivo e prova de urease positiva.

À exceção das 46 culturas, onde ocorreu crescimento bacteriano ( $23 \mathrm{em}$ meio de Thioglycollate e 23 em meio de Sabouraud-Dextrose líqüido), todas as demais culturas permaneceram estéreis por

\footnotetext{
- Hancock Laboratories, Inc., Anaheim, Califórnia, USA

.. O material para esta pesquisa foi fornecido por Labcor Laboratórios, Belo Horizonte, MG
} 
um período de incubação de 15 dias, no laboratório, não se verificando crescimento de microorganismos em nenhuma cultura nos meios Brain-HeartInfusion e Micosel, assim como nas demais $77 \mathrm{cul}$ turas em meio de Thioglycollate e 77 culturas em meio de Sabouraud-Dextrose liqüido.

A execução de testes posteriores com trocas sucessivas da solução de glutaraldeído contendo fragmentos de válvulas aórticas de porcino revelaram ser esta micobactéria resistente à ação do glutaraldeído em solução a $0,625 \%$ que não eliminou totalmente as micobactérias, permitindo seu crescimento em meios de cultura específicos e sua eliminação completa ocorreu após a ação do formaldeído em concentração de $4 \%$, $2 \%$ e mesmo a $1 \%$ associado ao surfactante.

\section{COMENTÁRIOS E CONCLUSÕES}

As endocardites com hemoculturas negativas, mais corretamente denominadas endocardites com culturas aparentemente negativas, incluem os casos de endocardites cujas hemoculturas tornam-se positivas após 72 horas, as que necessitam de técnicas e métodos especiais de culturas para crescimento bacteriano e as endocardites com hemoculturas negativas, mas culturas de tecido positivas. As principais causas de endocardite com aparentes hemoculturas negativas constituem o uso prévio de antibióticos, endocardite não infecciosa (febre reumática, lupus, endocardite marântica, mixoma, fibroelastose endocárdica, endocardite fibroblástica, síndrome carcinóide, organismos não bacterianos, endocardite do coração direito e endocardite por microorganismos do grupo fastidious ${ }^{16}$.

As bactérias do grupo fastidious, conhecidas como causadoras de endocardite, não crescem, habitualmente, nos meios de culturas nas primeiras 72 horas e, para certas espécies, as culturas só se tornam positivas após uma semana e meia a duas semanas. Mesmo assim, em muitos casos, as hemoculturas não serão reconhecidas como positivas a não ser que sejam utilizadas técnicas especiais de repiaue e meios especiais de cultura para seu crescimento, assim como técnicas especiais de identificação bacteriana. O grupo fastidious engloba o complexo fortuitum-chelonei.

Neste estudo experimental, verificou-se o crescimento bacteriano em $23 \%$ das culturas entre o 5 : e o 10 . dias, identificadas, posteriormente, como Mycobacterium chelonei, enfatizando a necessidade de manter a incubação destes meios de cultura por um mínimo de 15 dias, nos laboratórios envolvidos na fabricação de biopróteses.

Paralelamente a esta pesquisa, não incluídas no presente estudo, foram efetuadas provas de es- terilidade de fragmentos de válvulas aórticas de porcino que não haviam sido submetidas a nenhum processo de tratamento pelo glutaraldeído, assim como das soluções balanceadas utilizadas para a preservação do tecido biológico com e sem glutaraldeído.

Verificou-se que todas as amostras das soluções estavam absolutamente estéreis e que as micobactérias não cresceram nas culturas de fragmentos de valvas não tratadas pelo glutaraldeído. impedidas que foram pela presença maciça de outros microorganismos.

COLLINS \& MONTALBINE ${ }^{2}$ demonstraram que a solução alcalina de glutaraldeído a $1 \%(\mathrm{pH}$ 8,5 ) inativou mais de $99,9 \%$ das amostras de micobactérias em tempo inferior a 2 minutos, enquanto a solução ácida ( $\mathrm{pH} 3,7$ ), na mesma concentração, requereu o dobro de tempo para alcançar o mesmo indice de inativação. As soluções com concentração de glutaraldeído a $0,5 \%$, tanto ácida como básica, foram menos efetivas, mas mostraram o mesmo comportamento quanto ao tempo de inativação.

Finalmente, constatou-se a eliminação completa das micobactérias após a ação do formaldeído em concentração de $4 \%, 2 \%$ e mesmo a $1 \%$, associado a substâncias surfactantes.

Os casos de endocardite por Mycobacterium chelonei comprovadamente causados por biopróteses de porcino contaminadas relatados na literatura ${ }^{7}, 12,15$ demonstraram um longo período de incubação da doença (135 dias, 150 dias e 3 anos), assim como dificuldades para firmar o diagnóstico. que exigiu tempo prolongado de incubação das hemoculturas, utilizando-se meios e técnicas especiais de repique e subculturas.

É recomendada a terapêutica antituberculosa, quando se evidencia, clínica e laboratorialmente, a presença de endocardite por micobactérias do complexo fortuitum-chelonei.

Além de todos os cuidados de assepsia e antisepsia mencionados no decorrer de todo o processo de tratamento do tecido biológico e confecção das biopróteses, ressaltamos a importância da técnica de embalagem das biopróteses com relação ao tipo de solução de preservação, à qualidade da própria embalagem utilizada, particularmente com relação à sua resistência, absoluta impermeabilidade e inviolabilidade do lacre.

Todos estes cuidados são fundamentais na profilaxia das endocardites em pacientes que se submetem a implante de biopróteses valvulares cardiacas. 
CASAGRANDE, I. S. J.; LUCCIOLA, J.: SALLES, C. A. - Atypical mycobacteria on bioprostheses: potential cause for culture-negative endocarditis. Rev. Bras. Cir. Cardiovasc., 1(1): 40-43, 1986.

ABSTRACT: The growth of atypical mycobacteria was observed in experimental studies in vitro of porcine aortic valve (aortic wall coupon) after tanning in glutaraldehyde solution at $0.625 \%$. One hundred aortic wall coupons from different valves were incubated in 4 different culture media in a total of 400 cultures, employing the Thioglycollate, Brain-Heart-Infusion, liquid Sabouraud-Dextrose and Micosel, which did not become positive for 72 hours. The growth of atypical mycobacteria was recognized in $23 \%$ of the samples from the Thioglycollate and Sabouraud media after the 5 th day utilizing appropriate subculturing techniques and special culture media. The atypical mycobacteria were identifyed as the Mycobacterium chelonei, which was demonstrated to be resistant to glutaraldehyde and it was completely eliminated by the formaldehyde in association with the surfactant.

DESCRIPTORS: heart valve prosthesis; endocarditis; mycobacteria, atypical.

\section{REFERÊNCIAS BIBLIOGRÁFICAS}

1 CENTER FOR DISEASE CONTROL - Isolation of Mycobacteria species from porcine heart prostheses. MMWR, 26: 42-43, 1977

2 COLLINS, F. M. \& MONTALBINE, V. - Mycobactericida activity of glutaraldehyde solutions. J. Clin. Microbiol., 4: $408-412,1976$

3 GERACI, J. E.: ANDERSON, M. W. KARLSON, A. G. - Endocarditis due to a rapidly growing chromogenic mycobacterium. Mayo Clin. Proc., 43: 124-133, 1968.

4 HAND, W. L. \& SANFORD, J. P. - Mycobacterium fortuifum: a human pathogen. Ann. Intern. Med. 73 : 971-977, 1970

5 KURITSKY, J. N.; BULLEN, M. G.; BROOME, C. V.: SILCOX, V. A.; GOOD, R. C.; WALLACE Jr., R. J. Sternal wound infections and endocarditis due to organisms of the Mycobacterium fortuitum complex. Ann. Intern. Med, 98: 938-939, 1983.

6 LASKOWSKI, L. F.; MARR, J. J.: SPERNOGA, J. F.; FRANK, N. J.; BARNER, H. B.; KAISER, G.; TYRAS, D. H. - Fastidious mycobacteria grown from porcine prosthetic-heart-valve cultures. N. Engl. J. Med., 297:101-102, 1977.

7 LEVY, C.; CURTIN, J. A.; WATKINS, A.; MARSH, B.; GARCIA, J.; MISPIRETA, L. - Mycobacterium chelonei infection of porcine heart valves. N. Engl. J. Med., 297; $667-668,1977$

8 NARASIMHAN, S. L. \& AUSTIN. T. W. - Prosthetic valve endocarditis due to Mycobacterium fortuitum. Can. Med. Assoc. J., 119: 154-155, 1978.
9 REPATH, F.; SEABURY, J. H.; SANDERS, C V.: DOMER J. - Prosthetic valve endocarditis due to Mycobacterium chelonei. South. Med. J., 69: 1244-1246, 1976.

10 ROBICSEK, F.; DAUGHERTY, H. K.; COOK, J. W. SELLE, J. G.; MASTERS, T. N.; O'BAR, P. R.; FERNANDEZ, C. R.: MAUNEY, C. U.; CALHOUN, D. M. Mycobacterium fortuitum epidemics after open-heart surgery. J. Thorac. Cardiovasc. Surg., 75: 91-96, 1978.

11 ROCHSTEIN, E. - Summary of the 25th Research Conference in Pulmonary Diseases of the Veterans Administration-Armed Forces. Am. Rev. Respir. Dis., 91:612, 1966.

12 RUMISEK, J. D.; ALBUS, R. A.; CLARKE, J. S. - Late Mycobacterium chelonei bioprosthetic valve endocarditis: activation of implanted contaminant? Ann. Thorac. Surg., 39: 277-279, 1985.

13 SZABO, J. \& SARKOZI, K. - Letter to the Editor. Am. Rev. Respir. Dis., 121: 607, 1980.

14 TARSHIS, M. S. - The problem of the so-called unclassified mycobacteria in human disease. Tuberculology. 22: $13,1964$.

15 TYRAS, D. H.; KAISER, G.C.; BARNER, H. B.; LASKOWSKI, L. F.; MARR, J. J. - Atypical mycobacteria and the xenograft valve. J. Thorac. Cardiovasc. Surg., 75 : $331-337,1978$

16 VAN SCOY, R. E. - Culture-negative endocarditits. Mayo Clin. Proc, , 57: 149-154, 1982.

17 WAGLEY, P. F.; KRESS, M. B.; BEACHAM, E.G. - Some clinical observations on anonymous mycobacteria. Bull. Johns Hopkins Hosp., 117: 207-227, 1965. 